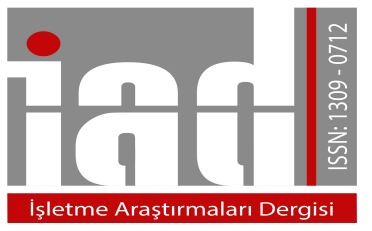

Journal Of

Business Research

Turk

www.isarder.org

\title{
The Relationship between Perceived Support and Innovative Behavior: Analyzing the Mediating Role of Work Engagement
}

\author{
Çağlar DOĞRU \\ Ufuk University \\ Department of Management and Organization \\ Ankara, Turkey \\ orcid.org/0000-0002-4215-8979 \\ caglar.dogru@ufuk.edu.tr
}

\begin{abstract}
This study reconnoiters the relationship between perceived support and individual innovative behavior at the workplace built on Social Exchange Theory and Job Demands-Resources model. In this research, perceived support was measured via organizational, supervisor, peer support through a multilevel lens. Furthermore, the mediator role of work engagement was questioned in the link between perceived support and work engagement. To achieve these, data obtained from a total number of 203 employees in five different firms operating in two separate Technoparks located in Ankara, Turkey. According to the results, perceived support of organization, supervisor and peer have significant positive effects on innovative behavior. Among the dimensions, most important affect was recorded by perceived organizational support. Also, it was indicated that work engagement had a partial mediator effect on the relationship between perceived support and innovative behavior.
\end{abstract}

Keywords: Perceived Support, Perceived Organizational Support, Perceived Supervisor Support, Innovative Behavior, Work Engagement

\section{Introduction}

Support from organization, supervisor and peer, enable employees to enhance their positive behaviors at work. In case they are supported by organization, not only they are more committed to it (Eisenberger, Huntington, Hutchison and Sowa, 1986), feel more job satisfaction (Rhoades and Eisenberger, 2002); but also their job involvement (O'Driscoll and Randall, 1999), organizational identification (Edwards, 2009) and performance levels (Wayne, Shore, Bommer and Tetrick, 2002) tend to increase. Furthermore, employees have positive attitudes towards their organizations and their jobs when they are also supported by their managers (Eisenberger, Stinglhamber, Vandenberghe, Sucharski and Rhoades, 2002) and peers (Woo and Chelladurai, 2012).

Although scholars have paid enough attention on predecessors and consequences of perceived support (e.g., Eisenberger, Cummings, Armeli and Lynch, 1997; Ghani and 
Hussin, 2009; Jawahar and Hemmasi, 2006;), besides the importance of individual innovative behavior of employees being accepted (Yuan and Woodman, 2010), it has still not received the attention it deserves (e.g., Scott and Bruce, 1994; Xerri, 2012). According to ILO World Employment Social Outlook (2017), innovation companies are the most productive companies which have competitive advantages for their survival. Innovative behaviors of employees enhance competitive advantages of firms which in turn enable them to survive in today's business world (Ancona and Caldwell, 1987; Leonard-Barton, 1992). This is because the origins of the organizational innovations are creative minds and innovative behavior of employees at individual level (Černe, Hernaus, Dysvik and Škerlavaj, 2017). For this reason, more and more organizations search ways to support their employees' innovative behaviors, today.

Primary focus of this research is, discovering a connection with employees' perceived support and their innovative behavior. Here, this link has been originated by norm of reciprocity (Gouldner, 1960). Secondly and widely it was built on Social Exchange Theory (SET) that has been attracted attention from many theorists (e.g., Blau, 1964; Gouldner, 1960; Homans, 1958; Malinowski, 1922; Thibault and Kelley, 1959). As providing a basis for social exchange theory, norm of reciprocity put forward that if someone receives a benefit from another, he/she feels obligation to behave favorably (Gouldner 1960). Likewise, SET states that if one side delivers valuable resources to opposite site and this site accepts and reciprocates, this means the exchange link has been generated (Blau, 1964). As in our case, it is expected to see a meaningful correlation between perceived support at work and innovative behavior of employees built on these theories.

Another argument of present research is to realize how work engagement effects interaction betwixt perceived support and innovative behavior. It stems from Job Demands-Resources model (JD-R) and this model consists of ' 'job demands"' and ' 'job resources". While "job demands" (Demerouti, Bakker, Nachreiner and Schaufeli, 2001) points out both somatic and mental efforts to do a job (i.e., work overload, job insecurity), "job resources" are mostly the motivators for achieving goals (i.e., support from others, job control) (Schaufeli, 2017). In this study, perceived support is taken as a "job resource" aimed at personnel who are passionate about their work (Macey and Schneider, 2008) to effect the individual innovative behavior. Accordingly, with the help of this study, a vital lack in the literature, which is investigating the intermediating influence of work engagement upon interactions among perceived support and innovative behavior is planned to be filled.

\section{Theoretical Framework}

\subsection{Perceived Support}

Perceived support of employees at workplace is stemmed from three main resources in general. This means, support at workplace can be in form of either perceived organizational support, or built on a study of Levinson (1965) it can be in form of perceived supervisor support. Furthermore, it may be in form of another important type of a social support which is peer or co-worker support (Bates, Holton,

Seyler and Carvalho, 2000; Woo and Chelladurai, 2012). Throughout this study, perceived support of employees are accepted to be divided into perceived organizational, supervisory and peer support, in order to enable us to reconnoiter the differences among these structures. 


\subsubsection{Perceived Organizational Support (POS)}

POS has been more emphasized by researchers than alternative types of support (i.e. Chen, Eisenberger, Johnson, Sucharski and Aselage, 2010; Rhoades and Eisenberger, 2002; Jawahar and Hemmasi, 2006). Staff constitutes a sense about how the organization appraises their contributions on both their work and organizational goals and objectives and also how organization gives importance for employees' wellbeing. This construct has been named as 'perceived organizational support' (POS) (Eisenberger et al, 1986).

POS was generated to explain employees' organizational commitment, built on social exchange links (Shore and Shore, 1995). When an organization values the efforts put by the employees to attain organizational goals and objectives and gives importance to their ideas and suggestions or promote their achievements (Rhoades and Eisenberger, 2002), consistent with social exchange theory, personnel shall have feelings of obligations to behave in favor of their organizations (Eisenberger, et al., 1997; Tekleab, Takeuchi and Taylor, 2005).

In case, employees are supported by their organization with regard to the conditions stated above, they tend to reciprocate positively to the organization. This may occur either by increasing the level of positive attitudes or behaviors towards the organization or by decreasing the level of negative attitudes or behaviors towards the organization. For example, when the degree of POS increases, the degree of organizational commitment (Eisenberger, Fasolo and Davis-Lamastro, 1990; Settoon, Bennett and Liden, 1996), job satisfaction (Stamper and Johlke, 2003), organizational citizenship behavior (Wayne, Shore and Liden, 1997), job involvement (Cropanzano, Howes, Grandey and Toth, 1997), work engagement (O'Driscoll ve Randall, 1999) and the degree of individual innovation (Eisenberger, et al., 1990) tend to increase. By contrast, when the degree of POS is high, employees' intentions to leave the organization (Arokiasamy, Marimuthu and Moorthy, 2010) and also their stress level (Rhoades and Eisenberger, 2002) tend to decrease.

Built on both JD-R model and SET, perceived support is taken as a valuable resource by employees. Being supported by the organization an employee has the opportunity to receive recognition, pay, promotions, job security and autonomy (Shore and Shore, 1995). This kind of work atmosphere decreases stress level of employees which successively enhances them to exert innovative behavior (Eisenberger, et al., 1990). As in this research, one of the main objectives is to reconnoiter and test the interactions among the sub-dimensions of perceived support, and there is a strong evidence on the interaction among POS and its' positive work-related outcomes (Wayne, et al., 1997) and innovative behavior (Eisenberger, et al., 1990), here it is convenient to hypothesize as:

Hypothesis 1a: Perceived organizational support has a positive relationship with innovative behavior.

\subsubsection{Perceived Supervisor Support (PSS)}

On the basis of organizational support theory, employees generate ideas about how their supervisors take their contributions into account, support them and care about their wellbeing. This is a separate form of support at work which is called as 'perceived supervisor support (PSS)' (Kottke and Sharafinski, 1988). This kind of perception of 
supervisor support stems from the idea which suggests that managers are the agents of the organization because in general they represent the organization and distribute resources in the name of the organization (Levinson, 1965).

According to researchers, it is evident that PSS and POS are related constructs (e.g., Rhoades, Eisenberger and Armeli, 2001; Yoon and Lim, 1999); the direction of the causality between these two constructs may be in both ways (Yoon and Thye, 2000).

Similar to organizational support, perceived supervisor support has favorable outcomes on positive work attitudes, while having unfavorable outcomes on withdrawal behaviors of employees (i.e. absenteeism and turnover) (Rhoades, et al., 2001). Moreover consistent with JD-R, supervisor support is among the job resources enabling employee wellbeing that in turn promotes both self-development and some other remarkable positive outcomes and innovative behavior (Schaufeli, 2017; Schaufeli and Bakker, 2004). So,

Hypothesis 1b: Perceived supervisor support has a positive relationship with innovative behavior.

\subsubsection{Perceived Peer Support (PPS)}

Another important source of support at workplace is perceived peer support (PPS) which includes support from employees in the same level of hierarchy working in the same department or team in the organization. As in the case of supervisor support, this type of support has been accepted as a branch of social support having important outcomes for work related behaviors (Baruch-Feldman, Brondolo, Ben-Dayan and Schwartz, 2002). It can be inferred from literature that PPS is as important as PSS. Because PPS explains antecedents of positive feelings and manners towards work (Bates, et al., 2000) and positive effects on work stress (Beehr, Jex, Stacy and Murray, 2000). According to Cohen and Wills (1985), support may be either 'structural', as the employee becomes part of a social group or 'functional', as the employee is supported by other employees in the network. In this study, peer support is taken as functional dimension of support.

Moreover, when the employee is supported by his/her peers at the workplace, his/her burnout and stress levels tend to decrease which in turn may support innovate behavior of the employee (Janssen, 2000). So, it can be hypothesized as:

Hypothesis 1c: Perceived peer support has positive relationship with innovative behavior.

After exploring the theoretical basis of perceived support, it should be analyzed the concept of innovative behavior so as to examine the interaction among stated concepts.

\subsection{Innovative Behavior}

Innovative behavior (IB) has been a charming research topic attracted by many scholars in recent times (e.g. Černe, et al., 2017; Anderson, Potočnik and Zhou, 2014; Kanter, 1988; Scott and Bruce, 1994). The reason for this is, innovation enables organizations to gain competences to survive and have competitive advantage over their rivals. And during this time, employees are a key factor in innovation process (Van de Ven, 1986). It consists of creating and implementing new perspectives and ideas (Janssen, 2004). Rather than just consisting generating new ideas and solutions for 
situations, innovation consists also implementing those ideas (Kanter, 1988). This means that innovation is a multiphase procedure that involves individual behaviors (Scott and Bruce, 1994).

Throughout this research, built on the relevant theoretical framework, innovative behavior is expected to be affected by perceived support and work engagements of employees. In the related literature, similar factors were examined to enlighten the antecedents of innovative behavior. Among these are, leader-member exchange (Scott and Bruce, 1994), supervisor support (Janssen and Van Yperen, 2004) and individual characteristics (Bunce and West, 1995).

According to Scott and Bruce (1994), individual innovative behavior has roots in four structures that are; "individual", "'leader", 'work group"' and "climate for innovation". This model fits well with the rationale behind this study. This is because, in the study of Scott and Bruce (1994), all the stated antecedents supported innovative behavior. This means, 'the leader' in their research model may correspond to the supervisor in this study. Also the 'work group' may correspond to the peers, 'climate for innovation' may correspond to organizational support and finally, 'individual factor' of the model may correspond to work engagement at the research.

\subsection{Work Engagement}

The interest that has been given on work engagement recently, owes it fame mostly to the concept of burnout (Bakker, Schaufeli, Leiter and Taris, 2008). Work engagement can be defined as, "positive, fulfilling, work-related state of mind that is characterized by vigor, dedication and absorption"' (Schaufeli, Salanova, GonzálezRomá and Bakker, 2002). As also Schaufeli and Bakker (2004) emphasize on 'active and favorable feeling' of work engagement, personnel are energetic and excited for work and are ready to exert efforts to accomplish their work related goals and objectives (Macey and Schneider, 2008).

Vigor means extreme dynamism that individuals have during their work or psychological endurance. Moreover, dedication is an employee's being involved in his/her own work with enthusiasm. In a similar manner, absorption points out an employee's high level of concentration on his/her work and even they are insensible of time while working (Schaufeli, et al, 2002). Moreover, 'absorption' would rather be evaluated as a consequence of work engagement, not a core dimension. (Salanova, Llorens, Cifre, Martínez and Schaufeli; 2003). Based upon this rationale, absorption has not accepted as a sub dimension of work engagement in this study.

Moreover, according to previous researches; job autonomy and support sources positively affect employees' work engagement (Xanthopolou, Bakker, Demerouti and Schaufeli, 2009). Therefore;

\section{Hypothesis 2: Perceived support has a positive relationship with work engagement.}

Since engaged employees are tireless and more eager to perform at a very high level at work, they tend to create new ideas and implement while working which means they enact innovative behavior. According to the related literature, it has been expected from work engagement to have mediating effect on the interaction among support and innovative behavior. For this reason here, it is hypothesized as: 
Hypothesis 3a: There is a mediating effect of work engagement on the relationship between perceived organizational support and innovative behavior.

Hypothesis 3b: There is a mediating effect of work engagement on the relationship between perceived supervisor support and innovative behavior.

Hypothesis 3c: There is a mediating effect of work engagement on the relationship between perceived peer support and innovative behavior.

To demonstrate the interaction among perceived support, work engagement and innovative behavior, indicated research model can be observed below.

Figure 1. Research Model

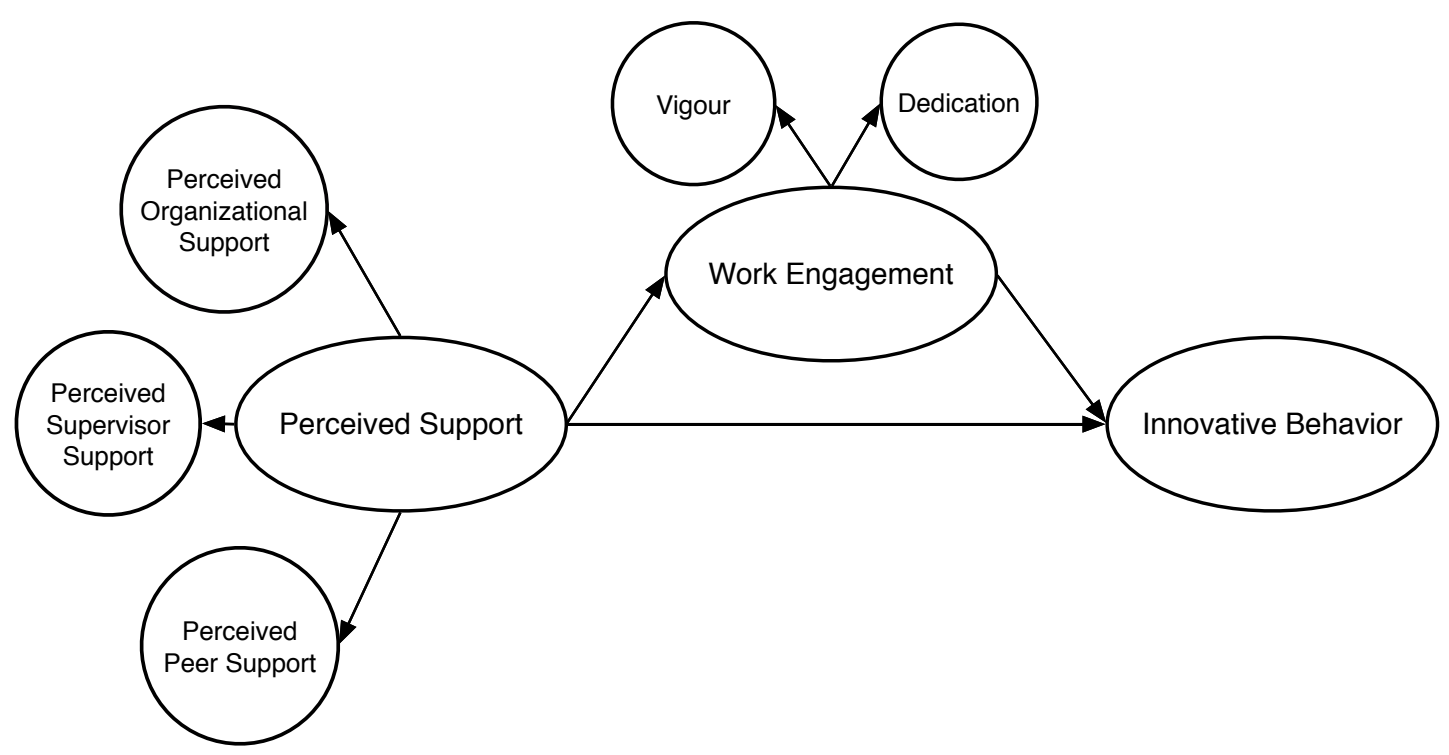

\section{Method}

\subsection{Procedure and Sample}

Quantitative research method was conducted in this research. In order to achieve this, surveys were delivered to all of the participants by hand. Employees from five different firms operating at two separate Technoparks located in Ankara, Turkey participated. Whereas three firms are among the leading companies operating in the information and communication sector, the other two firms operate in defense sector. They have put innovation in the first place in their corporate strategy.

Participation for the survey was voluntary for all of the respondents and also confidentiality was ensured on the basis of both individual employees and the firms. The total number of employees working at the selected firms was 220 at the time of research. Thus, 220 questionnaires delivered to all of the employees whereas, 203 completed questionnaires were returned with a response rate of 92 percent. 62 percent of participants were male and 36,5 percent were among the ages of 31 and 40 . Additionally, 63,5 percent of employees had undergraduate degree. Also the biggest 
group was the one that had tenure between six and ten years with 46,3 percent of participants. The demographic characteristics of participants can be observed at Table 1.

Table 1. Demographic characteristics of participants

\begin{tabular}{lcc}
\hline & f & \% \\
\hline Firm & & \\
A & 46 & 22,7 \\
B & 32 & 15,7 \\
C & 28 & 13,8 \\
D & 41 & 20,2 \\
E & 56 & 27,6 \\
\hline Gender & & \\
Female & 77 & 38,0 \\
Male & 126 & 62,0 \\
\hline Age & & \\
18-30 & 42 & 20,7 \\
31-40 & 74 & 36,5 \\
41-50 & 65 & 32,0 \\
50+ & 22 & 10,8 \\
\hline Education & & \\
High school & 18 & 8,9 \\
Two-year degree & 24 & 11,8 \\
Bachelor's degree & 129 & 63,5 \\
Postgraduate degree & 32 & 15,8 \\
\hline Tenure & & \\
0-5 years & 51 & 25,1 \\
6-10 years & 94 & 46,3 \\
11-15 years & 32 & 15,8 \\
15+ years & 26 & 12,8 \\
\hline Total & $\mathbf{2 0 3}$ & $\mathbf{1 0 0 , 0}$ \\
\hline
\end{tabular}

\subsection{Measures}

As measures were originally in English, they had been applied a back translation method because the participants were not native English (Brislin, 1986). The items had been translated from English to Turkish and then back to English. Before analyzing data, based on the directions of Tukey (1980), both exploratory and confirmatory analyses were conducted in order to provide validity for all the measures used in this study.

\subsubsection{POS Scale}

Perceived organizational support was measured on the eight-item scale suggested by Eisenberger, et al., (1997) which is a shortened format for original 36 item of perceived organizational support scale of Eisenberger, et al., (1986). A sample item: " "my organization really cares about my well-being." Cronbach's $\alpha$ of stated scale was .84. All the scales used throughout this study, were seven-point Likert Scale. (1: Strongly disagree. 7: Strongly agree.) The exploratory factor analysis results and Kaiser-Meyer-Olkin test and Bartlett Sphericity test results are shown at Table 2. 
Table 2. Factor loadings, KMO and Bartlett test results for POS scale

\begin{tabular}{|ccc|}
\hline Item No. & Factor Loadings & Variance (\%) \\
\hline 2 & 0,832 & 39,328 \\
4 & 0,810 & \\
1 & 0,765 & \\
5 & 0,732 & \\
7 & 0,685 & \\
6 & 0,616 & \\
8 & 0,602 & 0,78 \\
3 & 0,582 & 685,4 \\
\hline \multirow{2}{*}{ Kaiser-Meyer-Olkin (KMO) } & KMO and Bartlett Tests \\
\hline \multirow{2}{*}{ Bartlett Sphericity Test } & & 25 \\
\cline { 2 - 3 } & $\mathrm{X}$ & $0,000^{* * *}$ \\
\cline { 2 - 3 } & $\mathrm{Sd}$ & $\mathrm{p}$ \\
\hline
\end{tabular}

According to Ferguson and Cox (1993) the results, obtained at Table 2, are convenient for factor analysis. Based on the exploratory factor analysis, the scale was found to compose of one component with each item having factor loads over 0.5. Following the exploratory factor analysis, confirmatory factor analysis was also conducted and the results are turned out to be in the limits indicated by $\mathrm{Hu}$ and Bentler (1999). The results are shown at Table 3.

Table 3. Goodness of fit indices for POS scale

\begin{tabular}{|lccccc|}
\hline Scale & $\chi^{2} / \mathrm{df}$ & TLI & CFI & RMSEA & GFI \\
\hline POS & 2,33 & 0,91 & 0,93 & 0,06 & 0,94 \\
\hline
\end{tabular}

As seen on Table 3, the validity of the scale of perceived organizational support is provided.

\subsubsection{PSS Scale}

PSS scale was measured by 4 items of Rhoades, Eisenberger and Armeli (2001) which had been adopted from the original 36 item of perceived organizational support scale of Eisenberger, et al., (1986). A sample item is: "my supervisor cares about my opinions." Cronbach's $\alpha$ of this scale was .88. In order to test the validity for results of factor analysis that would be applied to data, again Kaiser-Meyer-Olkin and Bartlett tests were applied. Factor loadings and test results are present at Table 4. 
Table 4. Factor loadings, KMO and Bartlett test results for PSS scale

\begin{tabular}{|c|cc|}
\hline Item No. & Factor Loadings & Variance (\%) \\
\hline 3 & 0,764 & 34,259 \\
1 & 0,735 & \\
4 & 0,684 & \\
2 & 0,550 & 0,84 \\
\hline \multirow{3}{*}{ Kaiser-Meyer-Olkin (KMO) } & KMO and Bartlett Tests \\
\hline \multirow{2}{*}{ Bartlett Sphericity Test } & $\mathrm{X}^{2}$ & 980,6 \\
\cline { 2 - 3 } & $\mathrm{Sd}$ & 32 \\
\cline { 2 - 3 } & $\mathrm{p}$ & $0,000^{* * *}$ \\
\hline
\end{tabular}

According to Table 4, after exploratory analysis, it was observed that in this scale there is one component. After that, confirmatory analysis shows that goodness of fit indices for this scale is also in the range, as it can be seen at Table 5.

Table 5. Goodness of fit indices for PSS scale

\begin{tabular}{|lccccc|}
\hline Scale & $\chi^{2} / \mathrm{df}$ & TLI & CFI & RMSEA & GFI \\
\hline PSS & 1,93 & 0,93 & 0,95 & 0,07 & 0,96 \\
\hline
\end{tabular}

\subsubsection{PPS Scale}

To measure PPS, ten-item scale of Ducharme and Martin (2000) was used. Consistent with the aim of the research 'coworker/s' word was replaced by 'peer/s' in the scale. A sample item is: "my peers really care about me." Cronbach's $\alpha$ of this scale was .78. Like POS and PSS scales, same tests were conducted for PPS Scale which its results are demonstrated at Table 6 . According to factor analysis this measure was also revealed to have one component.

Table 6. Factor loadings, KMO and Bartlett test results for PPS scale

\begin{tabular}{|c|c|c|}
\hline Item No. & Factor Loadings & Variance $(\%)$ \\
\hline 3 & 0,912 & 38,749 \\
\hline 5 & 0,874 & \\
\hline 2 & 0,865 & \\
\hline 1 & 0,782 & \\
\hline 9 & 0,746 & \\
\hline 7 & 0,694 & \\
\hline 10 & 0,671 & \\
\hline 6 & 0,625 & \\
\hline 8 & 0,595 & \\
\hline 4 & 0,584 & \\
\hline \multicolumn{3}{|c|}{ KMO and Bartlett Tests } \\
\hline Kaiser-Meyer-Olkin (KMO) & & 0,90 \\
\hline \multirow{3}{*}{ Bartlett Sphericity Test } & $X^{2}$ & $1.120,5$ \\
\hline & $\mathrm{Sd}$ & 28 \\
\hline & $\mathrm{p}$ & $0,000^{* * *}$ \\
\hline
\end{tabular}
at Table 7.

Also, goodness of fit indices is convenient for PPS scale where they are present 
Table 7. Goodness of fit indices for PPS scale

\begin{tabular}{|lccccc|}
\hline Scale & $\chi^{2} / \mathrm{df}$ & TLI & CFI & RMSEA & GFI \\
\hline PPS & 1,86 & 0,95 & 0,96 & 0,05 & 0,97 \\
\hline
\end{tabular}

\subsubsection{Innovative Behavior}

To test self reported innovative behavior, ten-clause measure of Janssen, (2000) was used. An example item is like: 'I create new ideas for difficult issues." Cronbach's $\alpha$ of scale was .90 . Like perceived support scales favorable results were obtained from $\mathrm{KMO}$ and Bartlett tests for innovative behavior scale as it can be seen at Table 8. Also, according to factor analysis measure of innovative behavior was also revealed to have one component.

Table 8. Factor loadings, KMO and Bartlett test results for Innovative Behavior scale

\begin{tabular}{|c|c|c|}
\hline Item No. & Factor Loadings & Variance $(\%)$ \\
\hline 4 & 0,788 & 33,824 \\
\hline 2 & 0,763 & \\
\hline 9 & 0,742 & \\
\hline 10 & 0,710 & \\
\hline 8 & 0,682 & \\
\hline 6 & 0,674 & \\
\hline 3 & 0,633 & \\
\hline 7 & 0,590 & \\
\hline 5 & 0,562 & \\
\hline 1 & 0,535 & \\
\hline \multicolumn{3}{|c|}{ KMO and Bartlett Tests } \\
\hline Kaiser-Meyer-Olkin (KMO) & & 0,81 \\
\hline \multirow{3}{*}{ Bartlett Sphericity Test } & $\mathrm{X}^{2}$ & 576,2 \\
\hline & $\mathrm{Sd}$ & 21 \\
\hline & $\mathrm{p}$ & $0,000^{* * *}$ \\
\hline
\end{tabular}

Confirmatory factor analysis results for this scale are shown at Table 9 and they demonstrate good fit with data.

Table 9. Goodness of fit indices for Innovative Behavior scale

\begin{tabular}{|lccccc|}
\hline Scale & $\chi^{2} / \mathrm{df}$ & TLI & CFI & RMSEA & GFI \\
\hline $\begin{array}{l}\text { Innovative } \\
\text { Behavior }\end{array}$ & 2,65 & 0,90 & 0,92 & 0,08 & 0,91 \\
\hline
\end{tabular}

\subsubsection{Work Engagement}

Here eleven items formed by Schaufeli, et al., (2002) were used. Vigor was measured with 6 items. A sample item is: "at my work, I feel bursting with energy." Here Cronbach's $\alpha$ was .85. Dedication was assessed by five items. A sample item: 'I find the work that I do full of meaning and purpose.' Cronbach's $\alpha$ was .81. KMO and Bartlett test results can be analyzed at Table 10. According to the results, it is again meaningful to apply factor analysis. 
Table 10. KMO and Bartlett test results for Work Engagement scale

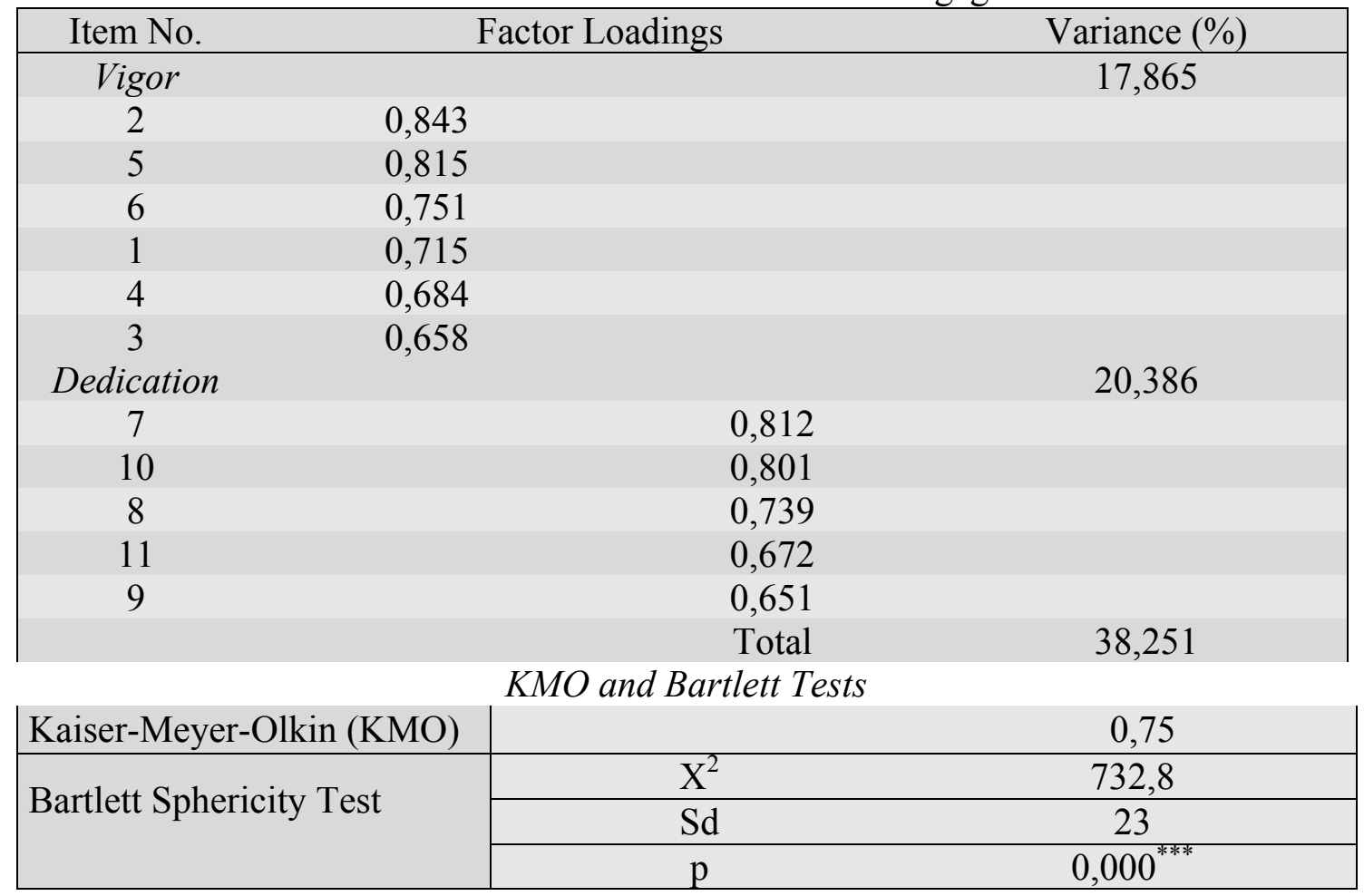

According to exploratory factor analysis, it was understood that work engagement has two components of vigor and dedication. Furthermore, goodness of fit indices complies with the limits which leads that work engagement scale is also valid according to Table 11 .

Table 11. Goodness of fit indices for Work Engagement scale

\begin{tabular}{|lccccc|}
\hline Scale & $\chi^{2} / \mathrm{df}$ & TLI & CFI & RMSEA & GFI \\
\hline $\begin{array}{l}\text { Work } \\
\text { Engagement }\end{array}$ & 2,92 & 0,94 & 0,96 & 0,07 & 0,93 \\
\hline
\end{tabular}

\subsection{Analysis and Results}

Means, standard deviations, correlations and reliabilities are demonstrated at Table 12.

Table 12. Means, standard deviations, correlations and reliabilities

\begin{tabular}{lllllllll}
\hline Variable & Mean & SD & 1 & 2 & 3 & 4 & 5 & 6 \\
\hline 1. POS & 4.38 & 1.38 & $(0.84)$ & & & & & \\
2. PSS & 3.76 & 1.65 & $0.18^{* *}$ & $(0.88)$ & & & & \\
3. PPS & 3.95 & 1.14 & $0.23^{* *}$ & $0.37^{*}$ & $(0.78)$ & & & \\
4. Vigor & 4.56 & 1.45 & $0.39^{* *}$ & $0.24^{* * *}$ & $0.35^{* *}$ & $(.85)$ & & \\
5. Dedication & 4.81 & 0.98 & $0.56^{* *}$ & $0.48^{* * *}$ & $0.41^{* *}$ & $0.18^{*}$ & $(.81)$ & \\
6. IB & 4.48 & 1.36 & $0.36^{* *}$ & $0.23^{* * *}$ & $0.31^{* *}$ & 0.58 & $0.49^{* *}$ & $(.90)$ \\
\hline
\end{tabular}

POS: Perceived Organizational Support; PSS: Perceived Supervisor Support; PPS: Perceived Peer Support; IB: Innovative Behavior.

${ }^{*} \mathrm{p}<0.05^{* *}: \mathrm{p}<0.01^{* * *}: \mathrm{p}<0.001$

According to Table 12, it can be inferred that, both perceived organizational, supervisor, peer support and work engagement have significant and positive links with innovative behavior (IB). 
For examination of mediating effect, three steps approach for testing mediation effect of Baron and Kenny (1986) acted a part. According to it, there should be a significant effect of independent variable on both mediator and dependent variable. The separate effects of perceived organizational, supervisor and peer support on work engagement and innovative behavior in all three steps of regression analysis are demonstrated at Table 13, Table 14 and Table 15 respectively.

Table 13. Three step hierarchical regression results for mediating effect, Independent Variable: Perceived Organizational Support

\begin{tabular}{|c|c|c|c|c|c|}
\hline \multicolumn{2}{|c|}{ Independent Variable } & $\begin{array}{c}\text { Dependent } \\
\text { Variable }\end{array}$ & $\begin{array}{c}\text { Adjusted } \\
R^{2}\end{array}$ & Dependent & $\begin{array}{c}\text { Adjusted } \\
R^{2}\end{array}$ \\
\hline & & $\begin{array}{l}\text { Innovative } \\
\text { Behavior }\end{array}$ & & $\begin{array}{c}\text { Work } \\
\text { Engagement }\end{array}$ & \\
\hline & & $\begin{array}{c}\text { Beta } \\
\text { Coefficient }\end{array}$ & & $\begin{array}{c}\text { Beta } \\
\text { Coefficient }\end{array}$ & \\
\hline Step & Model 1 & & & & \\
\hline 1. & POS & $0.38^{* *}$ & 0,357 & $0.27^{* *}$ & 0,341 \\
\hline 2. & Work Engagement & $0.42^{* *}$ & 0,473 & - & \\
\hline & \multicolumn{5}{|l|}{ Mediation Effect } \\
\hline \multirow[t]{2}{*}{3.} & POS & $0.21^{\text {*** }}$ & 0,546 & - & \\
\hline & Work Engagement & $0.48^{* *}$ & & - & \\
\hline
\end{tabular}

POS: Perceived Organizational Support

$*: \mathrm{p}<0.05 \quad * *: \mathrm{p}<0.01 \quad * * *: \mathrm{p}<0.001$

As seen on Table 13, When work engagement and perceived organizational support are included in Model 1 together, perceived organizational support's effect on innovative behavior decreases $\left(\beta_{\mathrm{POS}}=0,21, \mathrm{p}<0,01\right)$.

Table 14. Three step hierarchical regression results for mediating effect, Independent Variable: Perceived Supervisor Support

\begin{tabular}{|c|c|c|c|c|c|}
\hline \multicolumn{2}{|c|}{ Independent Variable } & & $\begin{array}{c}\text { Adjusted } \\
R^{2}\end{array}$ & $\begin{array}{c}\text { Dependent } \\
\text { Variable }\end{array}$ & $\begin{array}{c}\text { Adjusted } \\
R^{2}\end{array}$ \\
\hline & & $\begin{array}{c}\text { Innovative } \\
\text { Behavior }\end{array}$ & & $\begin{array}{c}\text { Work } \\
\text { Engagement }\end{array}$ & \\
\hline & & $\begin{array}{c}\text { Beta } \\
\text { Coefficient }\end{array}$ & & $\begin{array}{c}\text { Beta } \\
\text { Coefficient }\end{array}$ & \\
\hline Step & Model 2 & & & & \\
\hline 1. & PSS & $0.15^{* *}$ & 0,265 & $0.11^{* *}$ & 0,187 \\
\hline \multirow[t]{2}{*}{2.} & Work Engagement & $0.53^{* *}$ & 0,536 & - & \\
\hline & \multicolumn{5}{|l|}{ Mediation Effect } \\
\hline \multirow[t]{2}{*}{3.} & PSS & $0.08^{* *}$ & 0,408 & - & \\
\hline & Work Engagement & $0.65^{* *}$ & & - & \\
\hline \multicolumn{6}{|c|}{$\begin{array}{l}\Delta R^{2}: 0,143 \\
\text { Sobel Test: } Z_{2}: 5,482\end{array}$} \\
\hline
\end{tabular}

PSS: Perceived Supervisor Support.

$*: \mathrm{p}<0.05 \quad * *: \mathrm{p}<0.01 \quad * * *: \mathrm{p}<0.001$ 
According to Table 14, in case, work engagement and perceived organizational support are included in Model 2 together, perceived supervisor support's effect on innovative behavior decreases $\left(\beta_{\mathrm{PSS}}=0,08, \mathrm{p}<0,01\right)$.

Table 15. Three step hierarchical regression results for mediating effect, Independent Variable: Perceived Peer Support

\begin{tabular}{|c|c|c|c|c|c|}
\hline \multicolumn{2}{|c|}{ Independent Variable } & $\begin{array}{c}\text { Dependent } \\
\text { Variable }\end{array}$ & $\begin{array}{c}\text { Adjusted } \\
R^{2}\end{array}$ & $\begin{array}{c}\text { Dependent } \\
\text { Variable }\end{array}$ & $\begin{array}{c}\text { Adjusted } \\
R^{2}\end{array}$ \\
\hline & & $\begin{array}{c}\text { Innovative } \\
\text { Behavior }\end{array}$ & & $\begin{array}{c}\text { Work } \\
\text { Engagement }\end{array}$ & \\
\hline & & $\begin{array}{c}\text { Beta } \\
\text { Coefficient }\end{array}$ & & $\begin{array}{c}\text { Beta } \\
\text { Coefficient }\end{array}$ & \\
\hline Step & Model 3 & & & & \\
\hline 1 & PPS & $0.24^{* *}$ & 0,312 & $0.16^{*}$ & 0,235 \\
\hline \multirow[t]{2}{*}{2} & Work Engagement & $0.45^{* *}$ & 0,524 & - & \\
\hline & \multicolumn{5}{|l|}{ Mediation Effect } \\
\hline \multirow[t]{2}{*}{3.} & PPS & $0.19^{* *}$ & 0,498 & - & \\
\hline & Work Engagement & $0.55^{* *}$ & & - & \\
\hline
\end{tabular}

PPS: Perceived Peer Support.

$*: \mathrm{p}<0.05 \quad * *: \mathrm{p}<0.01 \quad * * *: \mathrm{p}<0.001$

According to Table 15, when work engagement and perceived peer support are included in Model 3 at the same time, again perceived peer support's effect on innovative behavior decreases $\left(\beta_{\mathrm{PPS}}=0,19, \mathrm{p}<0,01\right)$.

Consequently, both correlation and regression results presents that perceived organizational, supervisor and peer support have positive effects on innovative behavior (i.e. $\left.\beta_{\mathrm{POS}}=0,38, \mathrm{p}<0,01 ; \beta_{\mathrm{PSS}}=0,15, \mathrm{p}<0,01 ; \beta_{\mathrm{PPS}}=0,24, \mathrm{p}<0,01\right)$. Thus, $\mathrm{H}_{1 \mathrm{a}}, \mathrm{H}_{1 \mathrm{~b}}$ and $\mathrm{H}_{1 \mathrm{c}}$ are supported. Similarly, all support sources effect work engagement positively $\left(\beta_{\mathrm{POS}}=0,27, \mathrm{p}<0,01 ; \beta_{\mathrm{PSS}}=0,11, \mathrm{p}<0,01 ; \beta_{\mathrm{PPS}}=0,16, \mathrm{p}<0,01\right)$. So, $\mathrm{H}_{2}$ is also supported.

When work engagement and perceived support are included in each models together, perceived organizational, supervisor and peer support's effect on innovative behavior decreases in all cases $\left(\beta_{\mathrm{POS}}=0,21, \mathrm{p}<0,01 ; \beta_{\mathrm{PSS}}=0,08, \mathrm{p}<0,01 ; \beta_{\mathrm{PPS}}=0,19\right.$, $\mathrm{p}<0,01)$. This indicates a partial mediator effect of work engagement. Thus, $\mathrm{H}_{3 \mathrm{a}}, \mathrm{H}_{3 \mathrm{~b}}$ and $\mathrm{H}_{3 \mathrm{c}}$ are partially supported. Afterwards, for illustrating significance of mediating effect in each model, Sobel Tests were conducted. According to Sobel tests, the mediation role of work engagement is supported $\left(Z_{1}=4,254, p<0,01 ; Z_{2}=5,482, p<0,01\right.$; $\left.\mathrm{Z}_{3}=3,895, \mathrm{p}<0,01\right)$.

\section{Discussion and Conclusion}

Along this research, firstly it has been tried to examine a correlation among perceived support and innovative behavior. During the process, to test the links among these variables, perceived support at the workplace was divided into three sub dimensions as, perceived organizational, supervisor and peer support. Throughout the quantitative method of research and according to the analyzes built on the present 
research, it has been well revealed that, all the perceived support sources indicated in this research, are positively related to innovative behavior. According to the results obtained from data, perceived organizational support has the strongest positive link with innovative behavior. This shows if members notice that their organization supports innovative ideas, or other work-related extra efforts, suggestions or achievements and when they perceive it as the main source which distributes the valuable resources they need, they are more eager to demonstrate innovative behavior. This doesn't absolutely mean that other sources of support, which are supervisor and peers, don't have meaningful links with innovative behavior. On the contrary, both perceived supervisor and peer support have strong meaningful positive links with innovative behavior.

Comparing the obtained results throughout this study with other researches will provide a more concrete perspective on the issue. In this manner, Bos-Nehles and Veenendaal (2017) found a positive correlation between supportive supervisory and innovative behavior $(r=0.26 ; \mathrm{p}<0.001)$. This result is very close to the correlation found between the same variables in this study $(r=0.23 ; \mathrm{p}<0.001)$. In another research conducted among 486 employees working at a telecommunication company, Chen, $\mathrm{Li}$ and Leung (2016) found similar results with this study $(r=0.20 ; \mathrm{p}<0.001)$. In another research among 367 IT experts and engineers in Pakistan, Nazir, Shafi and Qun (2017) found that perceived organizational support positively effects innovative behavior of employees $\left(\beta_{\mathrm{POS}}=0,39, \mathrm{p}<0,05\right)$. This result again coincides with the one found in this study in terms of direction with a bigger magnitude $\left(\beta_{\mathrm{POS}}=0,21, \mathrm{p}<0,01\right)$.

Moreover, the regression analysis results demonstrate that when one of the social exchange parties is the organization itself, employees are eager to exert innovative behavior at work compared to other sources of support. This reveals that among the sources of support, POS has the biggest magnitude of effect on innovative behavior of employees. Surprisingly, rather than supervisor support, peer support has more powerful effect on innovative behavior. This may stem from participant employees' mostly working as a team member in their organizations and their positive team atmosphere.

In accordance with these results discussed, perceived support has also positive effects on work engagement. Among these results again, employees engage in work best if their wellbeing is important for the organization, which means they are supported by their organization. In addition to this when they have cohesion with their peers they feel more engaged to their work than they perceive supervisory support. From the perspective of mediation role of work engagement, it is proved that work engagement play a mediator role on the link among perceived organizational support and individual innovative behavior. Here the most important source of support turns out to be organizational support that has a vital effect on innovative behavior. These in turn, enlighten the road in which organizations and managers try to encourage innovative behavior of employees. They should foster the innovative atmosphere and value employees' innovative ideas and suggestions in order to sustain their effectiveness and efficiency.

\section{Directions For Future Research}

Since the research was conducted in a limited geography, generalization of the results may not be possible. To cope with this limitation, further research may enlarge the participant group, including individuals from different regions or countries, different 
cultures, etc. As discussed above, surprising results of perceived peer support, may have originated from the team dynamics of the employees participated in this study. So research should be concentrated on team atmosphere, when trying to lay down the links among support and innovative behavior on the basis of Job Demands-Resources model (JD-R).

Also in this study, quantitative method of research was conducted. It may add much if mixed research methods will be applied in future. Another direction for future study may be noted to mind other job resources in the link among perceived support, work engagement and innovative behavior on the basis of both social exchange theory and Job Demands-Resources model.

\section{References}

Ancona, D. \& Caldwell, D. (1987). Management issues facing new product teams in high technology companies. In D. Lewin, D. Lipsky \& D. Sokel (Eds.), Advances in industrial and labor relations, 4, 191-221. Greenwich, CT: JAI Press.

Anderson, N.R., Potočnik, K. \& Zhou, J. (2014). Innovation and creativity in organizations: A state-of-the science review, prospective commentary and guiding framework. Journal of Management, 40 (5), 1297-1333.

Arokiasamy, L., Marimuthu, M. \& Moorthy, M.K. (2010). A study on the perceived organisational support in the financial industry in Malaysia, a literature review. Interdisciplinary Journal of Contemporary Research in Business, 2 (7), 438-451.

Bakker, A.B. \& Demerouti, E. (2008). Towards a model of work engagement. Career Development International, 13, 209-223.

Bakker, A.B., Schaufeli, W.B., Leiter, M.P. \& Taris, T.W. (2008). Work engagement: An emerging concept in occupational health psychology. Work \& Stress, 22 (3), 187-200.

Baron, R.M. \& Kenny, D.A. (1986). The moderator-mediator variable distinction in social psychological research: Conceptual, strategic and statistical considerations. Journal of Personality and Social Psychology, 51, 6, 1173-1182.

Baruch-Feldman, C., Brondolo, E., Ben-Dayan D. \& Schwartz, J. (2002). Sources of social support and burnout, job satisfaction and productivity. Journal of Occupational Health Psychology, 7 (1), 84-93.

Bates, R.A., Holton, E.F. III., Seyler, D. L., Carvalho, M.A. (2000). The role of interpersonal factors in the application of computer-based training in an industrial setting. Human Resource Development International, 3 (1), 19-42.

Beehr, T.A., Jex, S.M., Stacy, B.A. \& Murray, M.A. (2000). Work stressors and coworker support as predictors of individual strain and job performance. Journal of Organizational Behavior, 21(4), 391-405.

Blau, P.M. (1964). Exchange and power in social life. New York: John Wiley. 
Bos-Nehles, A.C. and Veenendaal, A.A.R. (2017). Perceptions of hr practices and innovative work behavior: the moderating effect of an innovative climate, The International Journal of Human Resources Management, DOI: $10.1080 / 09585192.2017 .1380680$.

Brislin, R.W. (1986). The wording and translation of research instruments. In W.J. Lorner and J.W. Berry (Eds). Cross-cultural research and methodology series, 8. Field methods in cross-cultural research, 137-154. Thousand Oaks, CA, US: Sage Publications, Inc.

Bunce, D.\& West, M.A. (1995). Self perceptions and perceptions of group climate as predictors of individual innovation at work. Applied Psychology: An International Review, 44, 199-215.

Chen, T., Li, F. and Leung, K. (2016). When does supervisor support encourage innovative behavior? Opposite moderating effects of general self-efficacy and internal locus of control. Personnel Psychology, 69, 123-158.

Cohen, S. \& Wills, T.A. (1985). Stress, social support, and the buffering hypothesis. Psychological Bulletin, 98, 310-357.

Cropanzano, R., Howes, J.C., Grandey A.A. \& Toth, P. (1997). The link of organizational politics and support to work behaviors, attitudes, and stress. Journal of Organizational Behavior, 22, 159-180.

Černe, M., Hernaus, T., Dysvik, A. \& Škerlavaj, M. (2017). The role of multilevel synergistic interplay among team mastery climate, knowledge hiding, and job characteristics in stimulating innovative work behavior. Human Resource Management Journal, 27(2), 281-299.

Demerouti, E., Bakker, A. B., Nachreiner, F. \& Schaufeli, W. B. (2001). The job demands-resources model of burnout. Journal of Applied Psychology, 86 (3), 499512.

Ducharme, L.J \& Martin, J.K. (2002). Unrewarding work, coworker support and job satisfaction: A test of the buffering hypothesis. Work and Occupations, 27, 223243.

Edwards, M. R. (2009). HR, perceived organisational support and organizational identification: An analysis after organisational formation. Human Resource Management Journal, 19 (1), 91-115.

Eisenberger, R., Fasolo, P. \& Lamastro, V.D. (1990). Perceived organizational support and employee diligence, commitment and innovation, Journal of Applied Psychology, 75 (1), 51-59.

Eisenberger, R., Huntington, R., Hutchison S. \& Sowa D. (1986). Perceived organizational support. Journal of Applied Psychology, 71 (3), 500-507.

Eisenberger, R., Cummings, J., Armeli, S. \& Lynch P. (1997). Perceived organizational support, discretionary treatment and job satisfaction, Journal of Applied Psychology, 82 (5), 812-820.

Eisenberger, R., Stinglhamber, F., Vandenberghe, C., Sucharski, I.L., and Rhoades, L. (2002). Perceived supervisor support: Contributions to perceived organizational support and employee retention. Journal of Applied Psychology, 87 (3), 565-573. 
Ferguson, E. \& Cox, T. (1993). Exploratory factor analysis: A user's guide. International Journal of Selection and Assessment, 1(2), 84-94.

Ghani, N.A. \& Hussin, T.A.B. (2009). Antecedents of perceived organizational support. Canadian Social Science, 5 (6), 121-130.

Gouldner, A.W. (1960). The norm of reciprocity: A preliminary statement. American Sociological Review, 25 (2), 161-178.

Homans, G.C. (1958). Social behavior as exchange. American Journal of Sociology, 63, 597-606.

Hu, L. \& Bentler, P. (1999). Cut off criteria for fit indexes in covariance structure analysis: conventional criteria versus new alternatives. Structural Equation Modeling A Multidisciplinary Journal, 6 (1), 1-55.

Janssen, O. (2000). Job demands, perceptions of effort-reward fairness and innovative work behavior. Journal of Occupational and Organizational Psychology, 73(3), 287-302.

Janssen, O. (2004). How fairness perceptions make innovative behavior more or less stressful. Journal of Organizational Behavior, 25, 201-215.

Janssen, O. \& Van Yperen, N.W. (2004). The bright and dark sides of individual and group innovation: A special issue introduction. Journal of organizational Behavior, 25, 129-145.

Jawahar, I. M. \& Hemmasi, P. (2006). Perceived organizational support for women's advancement and turnover intentions: The mediating role of job and employer satisfaction. Women in Management Review, 21 (8), 643-661.

International Labour Office, (2017). World Employment and Social Outlook 2017: Sustainable enterprises and jobs: Formal enterprises and decent work. Geneva: International Labour Organization.

Kanter, R. (1988). When a thousand flowers bloom: Structural, collective, and social conditions for innovation in organizations. In B.M. Staw and L.L. Cummings (Eds.) Research in organizational behavior, 10, 169-211. Greenwich: JAI Press.

Kottke, J. L. and Sharafinski, C. E. (1988). Data analysis in social psychology. In D. T. Gilbert, S. Fiske and G. Lindzey (Eds.), The handbook of social psychology. New York: McGraw-Hill.

Leonard-Barton, D. (1992). Core capabilities and core rigidities: A paradox in managing new product development. Strategic Management Journal, 13, Special Issue: Strategy Process: Managing Corporate Self-Renewal (Summer,1992), 111125.

Levinson, H. (1965). Reciprocation: The link among man and organization. Administrative Science Quarterly, 9, 370-390.

Macey, W.H. \& Schneider, B. (2008). The meaning of employee engagement. Industrial and Organizational Psychology, 1, 3-30.

Malinowski, B. (1922). Argonauts of the western pacific: An account of native enterprise and adventure in the archipelagoes of Melansian New Guine. London: Routledge. 
Nazir, S., Shafi, A. and Qun, W. (2017). Impact of organizational justice and perceived organizational support on employees' innovative behavior. Australian \& New Zealand Academy of Management 2017 Conference, Melbourne, Australia.

O’Driscoll, M.P., \& Randall, D.M. (1999). Perceived organisational support, satisfaction with rewards, and employee job involvement and organisational commitment. Applied Psychology: An International Review, 48, 197-209.

Rhoades, L., Eisenberger, R. (2002). Perceived organizational support: A review of literature. Journal of Applied Psychology, 87 (4), 698-714.

Rhoades, L., Eisenberger, R. \& Armeli, S. (2001). Affective commitment to the organization: The contribution of perceived organizational support. Journal of Applied Psychology, 86, 825-836.

Salanova, M., Llorens, S., Cifre, E., Martínez, I. \& Schaufeli, W.B. (2003). Perceived collective efficacy, subjective well-being and task performance among electronic work groups: An experimental study. Small Group Research, 34, 43-73.

Schaufeli, W.B. (2017). Applying the job demands-resources model: A 'how to' guide to measuring and tackling work engagement and burnout. Organizational Dynamics, 46, 120-132.

Schaufeli, W.B. \& Bakker, A.B. (2004). Job demands, job resources and their link with burnout and engagement. Journal of Organizational Behavior, 25, 293-315.

Schaufeli, W.B., Salanova, M., González-Romá, V. \& Bakker, A.B. (2002). The measurement of engagement and burnout: A two sample confirmatory factor analytic approach. Journal of Happiness Studies, 3, 71-92.

Scott, S.G. \& Bruce, R. A. (1994). Determinants of innovative behavior: A path model of individual innovation in the workplace. Academy of Management Journal, 37 (3), 580-607.

Shore, L.M., \& Shore, T.H. (1995). Perceived organizational support and organizational justice. In R. Cropanzano and K. Kacmar (Eds.), Organizational Politics, Justice, and Support. Westport, CT: Quorum. 149-164.

Stamper, C.L. \& Johlke, M.C. (2003). The impact of perceived organizational support on the link among boundary spanner role stress and work outcomes. Journal of Management, 29 (4), 569-588.

Tekleab, A.G., Takeuchi R. \& Taylor, M.S. (2005). Extending the chain of links among organizational justice, social exchange and employee reactions: The role of contract vioalitions. Academy of Management Journal, 48, 146-157.

Thibault, J.W. \& Kelley, H.H. (1959). The social psychology of groups. New York: John Wiley.

Tukey, J. W. (1980). We need both exploratory and confirmatory, The American Statistician, 34 (1), 23-25.

Van de Ven, A. H. (1986). Central problems in the management of innovation. Management Science, 32, 590-607. 
Wayne, S.J., Shore, L.M., Bommer, W.H. and Tetrick, L.E. (2002). The role of fair treatment and rewards in perceptions of organizational support and leadermember exchange. Journal of Applied Psychology, 87 (3), 590-598.

Wayne, S. J., Shore, L.M. \& Liden, R.C. (1997). Perceived organizational support and leader-member exchange: A social exchange perspective. Academy of Management Journal, 40 (1), 82-111.

Woo, B. \& Chelladurai, P. (2012). Dynamics of perceived support and work attitudes: The case of fitness club employees. Human Resource Management Research, 2 (1), 6-18.

Xanthopolou, D., Bakker, A.B., Demerouti, E. \& Schaufeli, W.B. (2009). Reciprocal links among job resources, personal resources, and work engagement. Journal of Vocational Behavior, 74, 235-244.

Xerri, M.J. (2012). Workplace links and the innovative behaviour of nursing employees: a social exchange perspective. Asia Pacific Journal of Human Resources, 51 (1), 103-123.

Yoon, J. \& Lim, J. C. (1999). Organizational support in the workplace: The case of Korean hospital employees. Human Relations, 52, 923-945.

Yoon J. \& Thye S. (2000). Supervisor support in the work place: Legitimacy and positive affectivity. Journal of Social Psychology, 140, 295-316.

Yuan, F. \& Woodman, R.W. (2010). Innovative behavior in the workplace: The role of performance and image outcome expectations. Academy of Management Journal, 53 (2), 323-342. 